\title{
Chinese and Counterfactual Reasoning
}

\author{
Yan JIANG \\ yj9@soas.ac.uk
}

\begin{abstract}
This paper begins with a scrutiny of the notion SUBJUNCTIVE CONDITIONAL together with an introduction to the distinction of EXTRINSIC and INTRINSIC FACTORS affecting the nature of logical operators. This is followed by a cursory overview of psychological and grammatical researches on counterfactual expressions in Mandarin Chinese. It then sets out a list of tasks to be accomplished and explicates the author's view in a recent proposal that Mandarin counterfactuals can be formally divided into EXPLICIT and IMPLICIT counterfactuals, which cross-cut the tripartite division of TRUTHIFIERS, FALSIFIERS, and COUNTERPOSSIBLES. It is suggested that this understanding can serve as a unified framework to describe Chinese counterfactuals and can also be used to accommodate some related optative expressions found in several dialects.
\end{abstract}

Key words: counterfactual, conditional, Chinese

\section{On the notion SUBJUNCTIVE CONDITIONALS}

An essential asset of human thinking is its ability to make hypothesis on the basis of known facts or imagined situations, and to draw logical conclusions as a result. Hypothetical thinking makes it possible for humans to think beyond what is directly observable and contemplate alternative contingencies and displaced scenarios. Where such an act of rational thinking is linguistically communicated, we observe the use of INDICATIVE and SUBJUNCTIVE CONDITIONALS in many IndoEuropean languages. The naming of these two types of conditionals reflects the grammatical properties of such constructions, more specifically, the verb inflexion in Indo-European languages. Indicative conditionals take on verb morphology used for indicative mood, whereas subjunctive conditionals take on verbs in a variety of very special forms which are traditionally grouped together under the umbrella term SUBJUNCTIVE. This is illustrated here first with examples in French:

$$
\begin{aligned}
& \text { Il mangera } \\
& \text { He eat-IND-FUT- } 3^{\text {rd }} \_ \text {ps._sl. } \text { with us if we him-invite-IND-PRES- } 1^{\text {st }} \text {-ps.-pl. } \\
& \text { [IND=indicative mood, FUT=future tense, PRES=present tense, ps.= person, sl.= } \\
& \text { singular, pl.=plural }]
\end{aligned}
$$


"He will eat with us if we invite him."

Il mangerait avec nous

He eat-COND-PRES-3 ${ }^{\text {rd }}$ _ps._sl. with us

si nous l'invitions.

if we him-invite-IND-IMP-1 ${ }^{\text {st }}$-ps.-pl.

$[\mathrm{COND}=$ conditional $\operatorname{mood}($ the French conditionnel), IMP=imperfect tense(the French imparfait)]

"He would eat with us if we invited him."

Il aurait mangé avec nous

He have-COND-PAST-3 ${ }^{\text {rd }}$ _ps._sl eat-PST_PAR with us

si nous l'avions invité.

if we him-have-IND-PAST-PERF-1 ${ }^{\text {st }}$-ps.pl. invite-PST_PAR

[PAST=past tense (passé in French), PERF=perfect aspect, PST_PAR=past participle]

"He would have eaten with us if we had invited him."

The verb morphology of (1) can be described as INDICATIVE. Such conditionals take the form of PRESENT Or PRESENT PERFECT(in French, "passé compose") for PROTASIS (the if-clause, also termed THE ANTECEDENT) plus PRESENT, FUTURE, or IMPERATIVE for APODOSIS (the main clause, also called THE CONSEQUENT). But the morphology shown in (2) and (3) should be described as CONDITIONNEL in French grammar, being in the form of IMPERFECT or PLUPERFECT ( "plus-queparfait" in French) for protasis plus CONDITIONAL MOOD or CONDITIONAL PERFECT for the apodosis. We should take note of the fact here that the French subjunctive morphology is not used in conditional sentences. What is unreal is encoded as CONDITIONNEL in the apodosis, not in protasis. Turning now to some examples in English, the morphology in (4) is INDICATIVE, while those in (5) and (6), although described as SUBJUNCTIVE in earlier works of English grammar, are now taken to be no more than INCONGRUOUS PAST, "incongruous" because THE SIMPLE PAST is used to denote THE PRESENT, and THE PAST BEFORE PAST to denote THE SIMPLE PAST for protasis and the corresponding PAST MODAL "would" and its PERFECT FORM "would have" for apodosis, thus creating a TIME-DISTANCING EFFECT.

(4) If you arrive on time, you will catch the flight.

(5) If you arrived on time, you would catch the flight.

(6) If you had arrived on time, you would have caught the flight.

So SUBJUNCTIVE CONDITIONALS should not be taken as necessarily having the morphological property of subjunctive mood, as least not for French and English. Rather, they should be taken more from a semantic point of view, as expressing COUNTERFACTUAL REASONING, which is a type of conditionals exploring logical implications when the protasis explicitly presents a false situation, being either contrary to the fact or relating to some unimaginable, impossible or even contradictory scenarios. In contrast, indicative conditionals contain protasis whose truth value is "open", i.e. being either true or false. Through counterfactual hypothesis, one can exercise sophisticated 
thinking, make bold predictions and give profound judgments, all of which contributing significantly both to everyday thinking and to abstract metaphysical and scientific deliberation. ${ }^{1}$

\section{Extrinsic and intrinsic factors}

In propositional calculus, the four basic logical operators $\neg \wedge \vee \rightarrow$ carry purely logical properties in the sense that the very formal aspects of these operators determine the truth conditions of the compound propositions. Such formal aspects are called EXTRINSIC FACTORS. ${ }^{2}$ On the other hand, relations such as EXCLUSIVE DISJUNCTION and NECESSARY CONDITION exhibit INTRINSIC FACTORS that are only quasi-logical: the kind of meaning that cannot be ascertained just by examining the formal aspects of the formulae but is to be determined by making reference to the content of the whole formulae as well as the implicit use-context. (7) is a case of exclusive disjunction and (8) is to be interpreted as expressing a necessary condition.

For the set lunch, you can have either tea or coffee (but not both).

If you mow the lawn for me, I will pay you fifteen pounds. (= I will pay you only if you mow the lawn (if you don't, I won't).

Such intrinsic factors are not un-representable in propositional calculus, but their proper representation requires detour treatments, as shown in (9) and (10), which are translations of (7) and (8) respectively:

$$
\begin{aligned}
& (\mathrm{P} \vee \mathrm{Q}) \wedge \neg(\mathrm{P} \wedge \mathrm{Q})[\mathrm{P}=\text { One has tea; } \mathrm{Q}=\text { One has coffee. }] \\
& \mathrm{Q} \rightarrow \mathrm{P}[\mathrm{Q}=\mathrm{I} \text { pay you fifteen pounds; } \mathrm{P}=\text { You mow the lawn for } \mathrm{me}]^{3}
\end{aligned}
$$

Linguistic constructions can encode very specific intrinsic factors, such as using "as long as" to denote "sufficient condition" and "only if" to denote "necessary condition". They can also encode very general extrinsic factors, such as using "if... then" to denote CONDITIONALITY. In the latter case, the conditional is subject to varied interpretations depending on the content it expresses: SUFFICIENT or NECESSARY CONDITIONS or even COUNTERFACTUAL in indicative form such as (11) and (12), a matter of CONDITIONAL STRENGTHENING in a broad sense.

If you are the king, then I am the queen.

"If he says that two and two are five-well, two and two are five." [George Orwell: Looking Back on the Spanish War]

But INDICATIVE COUNTERFACTUALS are atypical for English, as most counterfactuals in the language are encoded with INCONGRUOUS PAST MORPHOLOGY so that just by examining the inflectional forms, they are comprehended as counterfactuals. This is also supposed to be the

\footnotetext{
${ }^{1}$ Cf. Jing-Schmidt (2017), which discusses the significance of counterfactual reasoning from psychological and sociological perspectives.

${ }^{2}$ The two notions EXTRINSIC and INTRINSIC FACTORS are credited to William of Ockham in Nickerson (2015) and are discussed at length in Sanford (2003).

${ }^{3}$ While (10) is a more accurate representation of the meaning of (8), pragmatic studies have revealed that language users often take (8) to mean "P $\leftrightarrow$ Q". That is, their unconscious comprehension habit tends to strengthen the "only if" meaning to the "if and only if" meaning.
} 
general picture for counterfactual conditionals in other Indo-European languages. But Mandarin Chinese and all other Han Chinese dialects seem to defy such a characterization. What are available as morphological features used to encode counterfactual hypothesis in Indo-European languages are not found in Chinese, making one wonder whether Chinese has counterfactual conditionals as linguistic devices and whether native speakers of Chinese are capable of counterfactual thinking at all.

\section{Current research issues}

The lack of overt morphological markings for Chinese counterfactuals engenders several important issues, even though it has also given rise to an ingrained nonchalance over the topic in the field of Chinese grammar in the past century. We look at the few available threads in turn.

\subsection{Are native Chinese speakers capable of thinking counterfactually and express such a thought in their mother tongue?}

Alfred Bloom raised this question in Bloom $(1981,1984)$ and concluded through questionnaire survey that the Chinese generally found it hard to answer questions that were contrary to fact and that the Chinese did not have in their command familiar linguistic means for them to make conscious use of, in order to express counterfactual thoughts. Bloom went on further to make a LINGUISTIC RELATIVITY argument ${ }^{4}$ based on the assumption that Chinese has no counterfactual markers: that the linguistic idiosyncracies of the Chinese language shape the way the Chinese think, which is ill-adapted to counterfactual reasoning.

Bloom's claims have met with sporadic disagreements since the nineteen eighties. The first line of reactions is adopted by some other psychologists. Au $(1983,1984)$ questioned Bloom's methodology and his stimulus designed, claiming that with improved test questions, Chinesespeaking subjects perform better in comprehending counterfactual meaning. But neither Bloom nor Au provided explanations on how exactly Chinese counterfactuals are encoded, expressed and comprehended. They designed some test questions which they felt to be interpretable as counterfactuals based on the English counterparts or on their understanding of Chinese, then put them to test to see whether the subjects' reactions would conform to the psychologists' expectation. Subsequent studies carried out by psychologists, such as Liu (1985), Cheng (1985), Wu (1994), Yeh and Gentner (2005), Feng and Yi (2006) and Hsu (2013, 2014), argue more or less against Bloom for two different reasons. One group challenge his premise that Chinese has no counterfactual markers and provided some other types of evidence to show that counterfactual markers do exist in Chinese. ${ }^{5}$ The other group agree with Bloom largely on his premise but challenge his experimental rigor, and then use their own experiments to reach the conclusion that even though Chinese has no counterfactual markers, Chinese people can still think counterfactually. These two types of views have different implications for the linguistic relativity hypothesis. While

\footnotetext{
${ }^{4}$ Also called the Sapir-Whorf Hypothesis.

${ }^{5}$ The thesis to be put forward in this paper takes sides with this group, claiming that Bloom's conclusion is based on the misconception that the subjunctive is the only linguistic device of counterfactual marking.
} 
neither supports a strong version of the hypothesis, only the latter version is sympathetic to the weak version of the relativity hypothesis: that the grammatical structures of a language impact on the mode of thinking of the language user to some extent. Chinese linguistics should be thankful to psychologists for having initiated research on Chinese counterfactuals and for having made important contributions. But it is also worth pointing out that such a study should presuppose an informed knowledge of linguistic analysis of the related structures couched in updated linguistic theories, which does not seem to be fully exploited in the above-mentioned psychological studies. ${ }^{6}$

The second line of reactions in response to Bloom's proposals is represented by Harbsmeier (1998) and Yuan (2015). In Volume VII:1 of Science and Civilization in China: Language and Logic by Christoph Harbsmeier, a sinologist, Chinese counterfactuals are discussed with criticisms to Bloom (1981). A subsection titled "Counterfactual conditional sentences" is presented in the book (Harbsmeier 1998: 116-118), in which Harbsmeier disagrees with Bloom and points out that in classical Chinese, 假使 jiăsh ̌̌ 'if' and 若使 ruòsh ‘ 'if', both renderable as 'if'-like words, always mark counterfactual clauses. He also observes that 微 wēi 'if not' in Pre-Qin classical Chinese is entirely limited to counterfactual usage, claiming that the noun mentioned after "wēi" must refer to something that is 'presupposed to have been non-existent'. The examples he gave were 微夫人 之力...... wēi fū rén zhī lì 'Without that person's help'(a nominal expression marked by 之), and 微夫子之发吾覆也 wēi fū ž̌ zhī fā wú fù yě 'But for the Master's lifting the veil for me' (a nominalized sentence, the marker also being 之) as well as 微太子言 wēi tàiž̃ yán 'Had it not been for (you) the Prince's words...' (nominal expression with marker 之 omitted). In addition, 微 wēi 'if not' can even come after the nominal subject: 君微出 jūn wēi chū 'If your highness had not left ...', indicating that "wëi" can also negate the predicate. Here, Harbsmeier seemed to have made a mistake. What is presupposed should be some eventuality that is existent, which is referred to by the nominal expression or the nominalized event after "wēi" or the event related to the predicate negated by "wēi". For Harbsmeier, the examples he cited suffice to prove that the Chinese have been using counterfactuals all the time. But he did not present an exhaustive list of available devices to express counterfactuality. In Yuan (2015), a lot more examples in classical Chinese are presented, some with dedicated counterfactual lexical markers as special negators or as conditional markers, others without, but with counterfactual interpretation inferable from contextual information. Since Yuan showed that some classical Chinese examples have contextually inferable counterfactual meaning, the dedicated counterfactual markers identified by Harbsmeier and Yuan can only be taken as the means to express counterfactual meaning on some occasions but not on others, when contextual inference is called for to obtain the counterfactual interpretation. Moreover, most of the dedicated markers of counterfactuality identified by Harbsmeier and Yuan have become obsolete. What is still in frequent use in ordinary language are 假使 jiăshǐ 'if' and 要不是 yàobúshì 'if-not-be', the latter being a modern variant of 微 weì ' if not'. The case of 假使 jiăshǐ 'if' was also discussed by Y. R. Chao, who remarked that the dozen or so ' if'-like words in Chinese form a gradient from the neutral conditionals to the least possible (Chao: 1968): 要是 yàoshì 'if’ [cognating with 若是 ruòshì 'if'], 要 yào 'if’, 假如 jiărú ‘if', 若是 ruòshì 'if'[如 rú 'if' and 若 ruò 'if' now used only in the style of classical Chinese], 倘若 tăngruò

${ }^{6}$ Cf. also Jing-Schmidt (2017), which gives critical reviews to many psychology works mentioned here. 
'if’, 假若 jiăruò 'if’, 假使 jiăshǐ 'if’, 倘使 tăngshǐ 'if’, 设若 shèruò 'if’. Reflecting on Chao's gradient in the present era, of the dozen words listed by Chao, a third of them have become obsolete. The remaining ones no longer exhibit any difference in probability in modern Chinese. This point was discussed by Jiang (2000), citing Lü (1956) in his favour.

\subsection{Goals and the topics to be treated here}

The above two lines of approach still leave open the following conjoined questions: how exactly counterfactual conditional reasoning is carried out in Chinese and what is the overall picture? To answer such questions, more general theories on Chinese counterfactuals need to be designed that should meet the following five requirements: 1) clearly state how counterfactual conditionals are phrased in Mandarin Chinese, 2) nicely accommodate some important claims about explicit and implicit counterfactuals in Chinese in the works extant, 3 ) identify the types of counterfactual conditionals and the use conditions of each, 4) provide a framework to describe some special constructions found in Han dialects/languages other than Mandarin, especially the optative constructions, and 5) reveal similarities and real differences between the counterfactual constructions in Han languages and some more inflection-reliant languages. The remaining sections of this paper take close looks at the data, but the findings are also used to introduce and refine a unified descriptive framework that makes some initial attempts at attaining the above five goals. It embodies a continuation from the position held by the first group of psychological studies reviewed above, maintaining that Chinese does have linguistic means to reach counterfactuality, but with a unified approach, claiming that there is a continuum in Chinese counterfactual marking from overt dedicated marker 要不是 yàobúshì 'if-not-be' to covert structural as well as diffuse lexical features. It then explicates a recent proposal that Chinese counterfactuals can be formally EXPLICIT or IMPLICIT, the two notions cross-cutting the tripartite division of TRUTHIFIERS, FALSIFIERS, and COUNTERPOSSIBLES. The typical explicit counterfactual in Mandarin is headed by the falsifier 要不是 yàobúshì 'if-not-be', which should best be treated as a unary operator prefixing a veridical $\mathrm{P}$, making the resulting construction categorically different from the lexically similar 要不然 yàobúrán 'if-not-so' or the more usual antecedent negation. Also discussed are some other constructions in Mandarin and in Wu dialects that are explicitly counterfactual, especially the truthifying 蛮好 meho 'be-good-that' construction in Shanghainese. The next topic concerns ways through which counterfactual meaning is reached via the use of a set of weak features in unmarked conditionals, whose real function is to pragmatically effect a change that will TRUTHIFY or FALSIFY a contingent situation rather than expressing counterfactuality directly. ${ }^{7}$ Substitution tests will be provided to demonstrate the subtle working of the weak features, including the perfective aspectual marker 了-le, the antecedent 早 zăo 'early' and the consequent 早 zăo 'early', the truthifying enhancer 真的 zhende 'really' and negation as the default falsifier. The final topic is about the COUNTERPOSSIBLES, including the COUNTER-IDENTICALS, showing that this type of counterfactuals makes no use of weak features in Chinese, just like similar cases in English that do not make use of FAKE-TENSE MORPHOLOGY.

\footnotetext{
${ }^{7}$ Both TRUTHIFY and FALSIFY are borrowed from Rescher (2007).
} 


\subsection{The case of "yàobúshì"}

The considerations given in Section 3.1 leave 要不是 yàobúshì 'if-not-be' to be the only extant "if"-expression in modern Mandarin that is dedicatedly marked for counterfactual conditionals. Relevant examples are given as (13) - (15).

$$
\begin{aligned}
& \text { yàobúshì wǒ yìng xià yītiáo xīn, gēnběn jiù cí bú liăo zhí, } \\
& \text { if-not-be I harden down one-CL heart, at-all hence resign not ASP post } \\
& \text { gèng lái bú liăo Běijīng } \\
& \text { also come not ASP Beijing } \\
& {[C L=\text { classifier; ASP = aspect marker }]} \\
& \text { 要不是我硬下一条心, 根本就辞不了职, 更来不了北京。 }
\end{aligned}
$$

"Had I not made up my mind, I would not have been able to resign at all, nor would I have been able to come to Beijing."

$$
\begin{aligned}
& \text { yàobúshì Hăo Hăidōng nà yǒudiăn yùnqì de jìnqiú , } \\
& \text { if-not-be Hao Haidong that rather luck DE1 goal } \\
& \text { píngjú kěndìng huì zhāo-lái bùmăn hé fēiyì } \\
& \text { draw certainly will cause dissatisfaction and criticism } \\
& \text { [DE1 }=\text { modifier/possessive marker }] \\
& \text { 要不是郝海东那有点运气的进球, 平局肯定会招来不满和非议。 }
\end{aligned}
$$

"Had it not been for Hao Haidong to score that rather lucky goal, a tie would surely have incurred dissatisfaction and complaints."

yàobúshì zhǔchírén dăduàn, hěn nán shuō gǔzhăng néng

if-not-be host interrupt very hard tell applause can

chíxù dào shēnme shíhòu

last to what time

要不是主持人打断,很难说鼓掌能持续到什么时候。

"Had it not been for the ceremony presenter who put the cheers to an end, it would have been hard to tell how long the applause would last."

“yàobúshi”" is very different from 要是...... 不 yàoshì...bú 'if ... not' or 要..... 不是 yào...búshì 'if ... not-be': the latter two bring about the negation of a proposition in the usual sense, yielding a protasis ambivalent between a counterfactual reading and an indicative reading, whereas the former one not only negates a proposition, but "closes it off" so that the whole protasis has only the dedicated counterfactual reading. Here, negation obviously plays a vital role, but negation is only a necessary condition, not a sufficient one. In the "yàoshì...bú" construction, which also forms a protasis, negation is also present, but the resulting protasis does not have to be contrary to fact. "yàobúshi" is to be viewed as a grammaticalized chunk also because as a chunk, it has a flexible distribution just like an "if" word, either prefixing the ensuing protasis or plugged in between the subject and the predicate of the protasis clause. 
An interesting observation can be made on the distinction between 要不是 yàobúshì 'if-notbe' and 要不然 yàobúrán 'if-not-so' ${ }^{8}$ In terms of morphological structure, these two chunks form a minimal pair. But in terms of usage, "yàobúrán" is a protasis containing a fusion of [if + not + discourse deixis (referring to a contextually salient situation)]. Thus "yàobúrán" acts as the protasis and is followed by a proposition serving as the apodosis. The resulting conditional is an indicative one, never a counterfactual one. No ambiguity between the factual and the counterfactual is detected.

If we take the role of the "yàobúshi" chunk as taking in a necessarily true proposition as its argument and returning a counterfactual protasis, it is tentamount to saying that the whole protasis is also a fusion of "yàobúsh'" and the ensuing proposition, which is likely to reopen the old debate on whether the "if" word is a BINARY OPERATOR or a UNARY OPERATOR. The debate concerns the mapping between logical operators and natural language expressions. In propositional logic, the arrow operator $\rightarrow$ denotes conditionality and is a two-place infix operator or a binary operator for short, taking in the protasis and the apodosis as its two arguments. Then the "if"-word could be taken as a binary term as well, representable as $\operatorname{IF}(\mathrm{P}, \mathrm{Q})$. Some logicians argue for a unary analysis of IF, taking it to combine with the protasis only, but the unary analysis is a lone voice. ${ }^{9}$ Yet in the case of "yàobúshi", "yào" is fused with "búshì" to make it different from the usual "if ... not..., Q " construction, but "búshi" still takes the protasis $\mathrm{P}$ in its scope and exerts negation force over it, making "yàobúshì" behave more like a unary operator, with only the protasis as its argument. Then the structure of the whole conditional should be taken as [ ["yàobúshi” P], Q], contrasting markedly with the indicative counterpart, which has the structure ["yàoshi”" [P, Q]].

Hsu $(2013$, 2014) report psycholinguistic experimental studies on Chinese counterfactual reasoning. Based on findings from her study on the use of "yàobúshì", Hsu concluded that “... counterfactual reasoning was accessible without contextual cues in Chinese" and thought her study "challenged the traditional view that counterfactual thinking is exclusively available through discourse in conversational Chinese due to the lack of a subjunctive mood". Hsu's alleged challenge does not seem to hold water. Works on Chinese conditionals published before Hsu's works, if they discussed the issue of counterfactuality at all, have noticed the availability of "yàobúshì" and its equivalents in classical Chinese as dedicated counterfactual markers. ${ }^{10}$ But they have also taken note of the fact that, while counterfactual reasoning is indeed accessible without contextual cues in Chinese when "yàobúshi" is used, there could be many other ways to express counterfactual thinking which make no use of "yàobúshi". It is those counterfactual uses which lack explicit markers, in contrast to "yàobúshì", that have been identified as carrying counterfactual meaning and comprehensible as such through discourse in conversation.

One swallow doesn't make a summer. Native speakers of Mandarin would readily agree that not all counterfactual thinking are expressed through "yàobúshì" construction. Many more are in fact expressed as implicit counterfactuals which will be looked at in the next section, not as explicit

\footnotetext{
${ }^{8}$ This is arguably the first time the distinction is drawn, as the two chunks have never been viewed as a minimal pair before.

${ }^{9}$ Cf. Bennett 2003 and his citation of Victor Dudman's works.

${ }^{10}$ Cf. Chen (1988) and Jiang (2000).
} 
counterfactuals headed by “yàobúshì”. Moreover, probably not many native speakers have realized that "yàobúshi" imposes a stringent constraint on the content of the protasis proposition. That is, some counterfactual ideas are ineffable with "yàobúshi" without rearrangements. As an experiment, try to translate into Chinese Blaise Pascal's famous remark, "If Cleopatra's nose had been shorter, the whole face of the world would have been changed."11 A colloquial rendering would take the form of (16), which involves extensive rearrangements to make the protasis fit into the metalevel prefix "yàobúshì". (17) appears to be nearer to the English counterpart, but has to take on an extra layer of negation so as to match the negative meaning of the if-not-be prefix. As another experiment, think how hard it would be to interpret a "yàobúshi" protasis containing a double negation, as shown in (18). A check at Beijing University Modern Chinese Corpus revealed that no double negation was found to follow "yàobúshì", even though single negation can occasionally be found, as shown in (19). This finding indicates that "yàobúshi" cannot accommodate multiple negation. The last point is that what follow "yàobúshì" seem to be rather down-to-earth, contingent events or states, and no abstract thoughts can be prefixed by it. ${ }^{12}$ Consequently, other means to reach counterfactuality, if at all available, will have to be employed for abstract counterfactuals, which may also be usable for more worldly counterfactuals.

$$
\begin{aligned}
& \text { yàobúshì āijí yànhòu de bízi nàme tǐngbá xiùlì , } \\
& \text { if-not-be Egypt beauty-queen DE1 nose that straight pretty } \\
& \text { shìjiè lìshǐ jiù huì shì lìng yîān miànmào le } \\
& \text { world history hence will be other one-CL look SFM } \\
& \text { 要不是埃及艳后的鼻子那么挺拔秀丽, 世界历史就会是另一番面貌了。 } \\
& \text { [SFM = sentence final marker] } \\
& \text { “If-not-be the Egyptian Queen's nose [be] so straight [and] pretty, world history } \\
& \text { would be of a different situation.” } \\
& \text { yàobúshì àijí yànhòu de bízǐ méi zhăng dé duăn diăn-ér, } \\
& \text { if-not-be Egypt beauty-queen DE1 nose not-PEF grow DE2 short a-bit }
\end{aligned}
$$

\footnotetext{
${ }^{11}$ In its French original: Le nez de Cléopâtre, s'il eut été plus court, toute la face de la terre aurait changé.

12 On this last point that no abstract thoughts can be prefixed by "yàobúshì", a familiar example can be examined, which was used by Bloom (1981) as a test question:

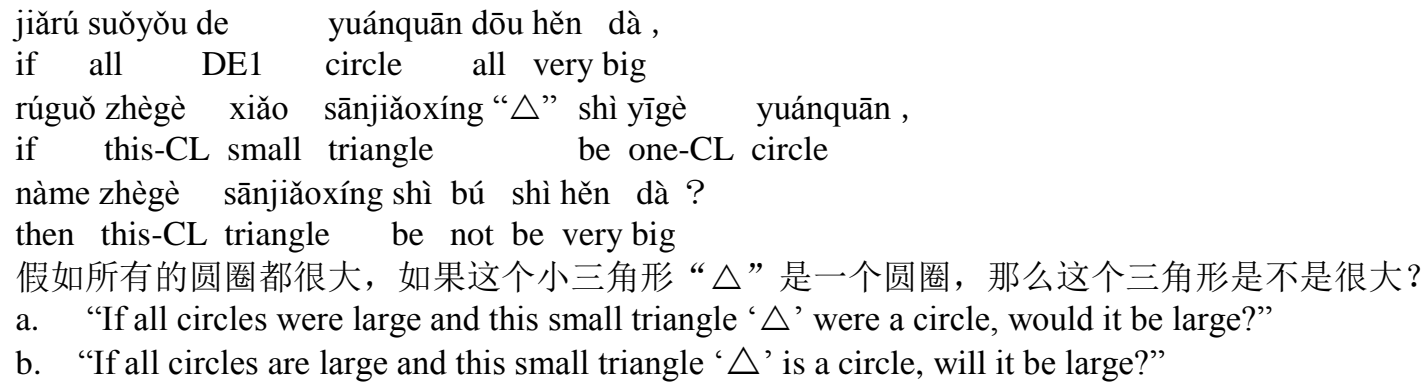

(i) is an example containing a series of propositions that are abstract in content. The example takes on the form of "jiărú $\mathrm{P}$, rúguǒ $\mathrm{Q}$, nàme $\mathrm{R}$ " (roughly equivalent to "If $\mathrm{P}$, if $\mathrm{Q}$, then $\mathrm{R}$ "), which can be comprehended either as an open conditional or as a counterfactual one - nothing in form marks it as counterfactual. But there is no natural way to rephrase the example with a prefix "yàobúshì". The difficulty remains the same even if either of the two protases is removed. 
shìjiè lìshǐ jiù huí shì lìng yīfān miànmào le world history hence will be other one-CL look SFM $[\mathrm{PEF}=$ perfective; $\mathrm{DE} 2=$ result marker $]$ 要不是埃及艳后的鼻子没长得短点儿，世界历史就会是另一番面貌了。 "If-not-be the Egyptian Queen's nose not grow shorter, world history would be of a different situation."

(18) ? yàobúshì wǒ niánqīng shí méi dăsuàn bú shàngxué , if-not-be I young time not-PEF intend not go-to-school xiànzài nă huì zài dàxué dāng jiāoshī ne now how can at university do teacher $Q$ $[\mathrm{Q}=$ question marker $]$

要不是我年轻时没打算不上学, 现在哪会在大学当教师呢?

"Had it not been the case that I didn't intend not to go to school when I was young, how could I have become a university teacher now?" yàobúshì tā qiāngfã bú zhŭn , if-not-be he shooting-skill not accurate zǐdàn shāoshāo piānlí le xīnzàng , bullet a little deviate ASP heart tā zăo yīmìngwūhū le he early die ASP 要不是他枪法不准,子弹稍稍偏离了心脏,他早一命鸣呼了。 "If-not-be he had not aimed accurately and the bullet had missed the heart, he would have kicked the bucket in no time."

\subsection{Implicit counterfactuals and weak features}

Given that "yàobúshi" does not provide the only route to reach counterfactuality in Mandarin, the only other available route seems to be to use unmarked conditionals to express either indicative or counterfactuals and let the context provide pragmatic cues to facilitate the comprehender's meaning-construction. However, current studies have revealed a third route: cues can also be provided by a cluster of unnoticeable weak features or lexical items that contribute, sometimes jointly, to the reach of counterfactual meaning. ${ }^{13}$ It has been found that the use of the following can contribute to counterfactual meaning: the aspectual suffix $了{ }_{1}$ le $_{1}$ ' optional marker of perfective aspect', the sentence final marker 了 ${ }_{2} \mathrm{le}_{2}$ 'denoting the change of state or emergence of a situation', the temporal adverb 早 zăo 'early' either in protasis or in apodosis, the negation words such as 不 bư' 'not' and 没 méi 'not-PEF', and the emphatic adverb 真的 zhēnde 'really'.

yàoshì nǐ qù le, jiù bú huì bú zhùyì tā nà piàoliàng de tàitài de if you go ASP, hence not will not notice he that pretty DE1 wife AM [AM $=$ assertion marker $]$

${ }^{13}$ Cf. Chen (1988), Jiang (2000), Wang (2013), Yuan (2015) and Yong (2016). 
要是你去了, 就不会不注意他那漂亮的太太的。

"If you had been there, you would not have failed to notice his pretty wife." rúguǒ wǒ zăo zhīdào tā bù lái, wǒ yě bú huì lái le

if I early know he not come, I also not will come SFM 如果我早知道他不来, 我也不会来了。

"If I knew it earlier that he would not come, I would not come either."

yàoshì tā kěn tuō rén shuō yījù hăo huà ,

if he agree ask someone say one-CL good word

wǒ zăo jiù gěi nàjiā gōngsī lùyòng le

I early hence by that-CL firm hire SFM

要是他肯托人说一句好话, 我早就给那家公司录用了。

"If he was willing to put in a good word for me through some contacts, I would have been hired by that company."

yàoshì wǒ zhēnde zhòng le liùhécăi, nà wǒ măshàng jiù huì cízhí

if I really hit ASP Mark-Six, then I immediately hence will resign

要是我真的中了六合彩, 那我马上就会辞职。

"If I really won the Mark Six, I would quit my work immediately."

yàoshì gāngcái nàgè rènyìqiú méi fá-jìn,

if just-now that-CL freekick not-PEF shoot-in,

jiù huì tī jiāshísài le

hence will kick extra-time-match SFM

要是刚才那个任意球没罚进, 就会踢加时赛了。

"If that free-kick had not been in, the match would have gone into extra-time."

While several weak features have been repeatedly identified in the literature as contributing to counterfactual meaning, the exact function of each is not at all clear in this context. Some highly tentative thoughts are presented here in anticipation of more cogent explanations. ${ }_{1} l_{1} e_{1}$ marks the occurrence of an event or change of a state which, if mentioned as a hypothetical one, can serve as a contrast to the reality. Likewise, if the initiation of a new situation by the sentence-final marker $了_{2} \mathrm{le}_{2}$ does not match the real-world scenario, a what-if-otherwise implicature is conveyed. 早 zăo 'early' in the protasis points vaguely to some time earlier than the reference time, to which a hypothetical event can be hooked, whereas 早 zăo 'early' in the apodosis conveys a modal meaning of volitional judgment, sometimes also showing the speaker's regret or disbelief, thereby giving the apodosis an optative reading.

Both "le 1 ", "le 2 " and "zăo" are reminiscent of the temporal-distancing effect in counterfactual conditionals of English and other Indo-European languages, where past morphology is used to depict a counterfactual present, and the past before past is used to depict a counterfactual past. 真 的 zhēnde 'really', when used in a protasis, always implicates that reality is to the contrary - that the eventuality modified by "zhēnde" does not really happen. Finally negation, though not a dedicated counterfactual marker as "yàobúshì", can easily provide an alternative scenario which, 
in proper contexts, could be taken as contrary-to-fact, especially when it takes on the perfective form 没“"méi”. The following set of sentences show minimal differences that are worthy of scrutiny.

yàoshì zhègè rènyìqiú fá-jìn le ,

if this-CL freekick kick-in SFM

jiù huì tī jiāshísài le

hence will kick extra-time-match SFM

要是这个任意球罚进了, 就会踢加时赛了。

a. "If this free-kick is in, the match will go into extra time."

b. "If this free-kick were in, the match would go into extra time."

(26) yàoshì zhègè rènyìqiú fá-bú-jìn ,

if this-CL freekick shoot-not-in

jiù huì tī jiāshísài le

hence will kick extra-time-match SFM

要是这个任意球罚不进, 就会踢加时赛了。

a. "If this free-kick is not in, the match will go into extra time."

b. "If this free-kick were not in, the match will go into extra time."

yàoshì zhègè rènyìqiú méi fá-jìn ,

if this-CL freekick not-PEF shoot-in

jiù huì tī jiāshísài le

hence will kick extra-time-match SFM

要是这个任意球没罚进, 就会踢加时赛了。

a. "If this free-kick were not in, the match would go into extra time."

b. "If this free-kick is not in, the match will go into extra time."

(28) yàoshì nàgè rènyìqú fá-jìn le ,

if that-CL freekick shoot-in SFM

jiù huì tī jiāshísài le

hence will kick extra-time-match SFM

要是那个任意球罚进了, 就会踢加时赛了。

"If that free-kick had been in, the match would have gone into extra time."

(29) yàoshì zhègè rènyìqiú zhēnde fá-jìnqù le ,

if this-CL freekick really shoot-go-in SFM

jiù huì tī jiāshísài le

hence will kick extra-time-match SFM

要是这个任意球真的罚进去了, 就会踢加时赛了。

"If this free-kick were really in, the match would go into extra time."

(30) yàoshì nàgè rènyìqiú zhēnde fá-jìnqù le ,

if that-CL freekick really shoot-go-in SFM

jiù huì tī jiāshísài le 。

hence will kick extra-time-match SFM 
要是那个任意球真的罚进去了, 就会踢加时赛了。

"If that free-kick were really in, the match would go into extra time."

yàoshì nàgè rènyìqiú zhēnde fá-jìnqù $\mathrm{le}$,

if that-CL freekick really shoot-go-in SFM

bǐsài zăo jiù jiéshù le ,

match early hence end SFM

hái tī shíme jiāshísài !

and kick what extra-time-match

要是那个任意球真的罚进去了, 比赛早就结束了, 还踢什么加时赛！

"If that free-kick were really in, the match would be over already. What extra time match needs to be played!"

yàoshì zăo fá-jìn nàgè rènyìqiú ,

if early shoot-in that-CL freekick

bǐsài jiù jiéshù le,

match hence end SFM

hái tī shíme jiāshísài !

and kick what extra-time-match

要是早罚进那个任意球, 比赛就结束了, 还踢什么加时赛！

"If that free-kick were in in good time, the match would be over. What extra time match needs to be played!"

(25) can be interpreted as either an indicative conditional or a counterfactual one. When using the proximal demonstrative "this free-kick", the situation under discussion is right in front of the eyes. It could be just over, giving rise to a counterfactual reading, or is just about to begin, making the sentence an open conditional. The presence of "le" here is not decisive enough to produce a counterfactual reading. (26) and (27) each have binary readings for the same reason. (27) also reveals the fact that "méi" had better be characterized as "perfective negation", not as "past negation", as it may be used to describe an event about to happen. (28) differs from (25) in using the distal demonstrative "that free-kick" instead of "this", which refers to the situation under discussion as a past and alternative event. Then 'le' contributes to the alternation of the event, leading to a counterfactual reading. (29) and (30) contain both "le" and "zhēnde", turning the conditionals into counterfactuals. (31) shares with (30) the same protasis. Yet (31) adds a "zăo" to its apodosis. Counterfactual reading becomes prominent as a result. Lastly, (32) contains a "zăo" in its protasis, thereby giving the sentence a counterfactual reading.

While weak features independently or in varied combinations contribute to the reach of counterfactuality, none poses a sufficient nor necessary condition, hence the name. Although sophisticated accounts could be given to explain the subtle working of these features, one undeniable fact is that these features are all dispensable, and counterfactuality can still be reached without the presence of any. The presence of "le" here is worth more discussion. Although "le" serves the more usual roles of aspectual marker and sentence-final marker in many sentences, here, what is at issue is the special case of using "le" to create a contrast between two propositions with 
and without "le". The proposition containing "le" can carry a counterfactual flavour because protasis in indicative conditionals is assumed to express an irrealis proposition, but the introduction of "le" forces the proposition to take on a realis form. "zăo" and "zhēnde" can create similar effects individually. Thus a non-occurring situation is pretended to have taken place, which is what counterfactuals set out to express, and the co-occurrence of two or more such weak features will strengthen the counterfactual effects

\section{Towards a unified description of Chinese counterfactuals}

Discussions in the sections above leave a rather fragmentary picture of Chinese counterfactuals that can hardly give a clear answer to the question that was raised at the beginning: how is counterfactual reasoning expressed in Chinese? In some recent works of mine, some initial attempts have been made to design a unified descriptive framework for Chinese counterfactuals (Jiang 2014; 2016). The thesis therein is carried over to the present discussion as a line of thinking worthy of explication and expansion. In Jiang $(2014$; 1016), I take note of the fact that "yàobúshì"counterfactuals in Mandarin have some parallel expressions both in Mandarin and in other dialects, expressing counterfactual meaning with conditional sentences or with optative constructions:

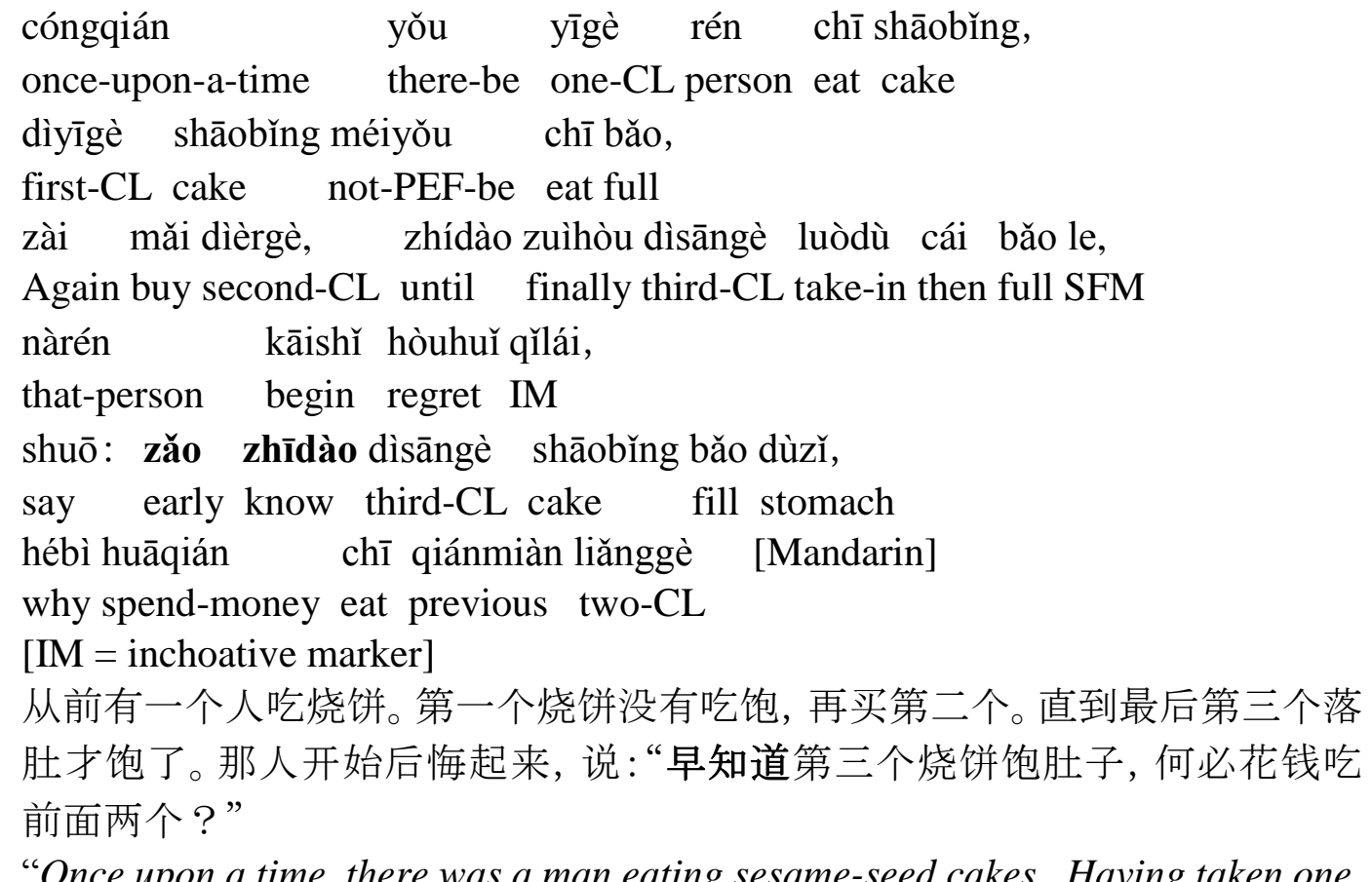
he was still hungry. So he bought another one, and the third. Then he was full but started to regret, 'Had I known the third one would make me full, I wouldn't have spent money on the first two!" ",

(34) zhèchăng huǒ, xìngkuī xiāofángduì lái dé zăo, zhis-CL fire lucky fire-brigade come DE2 early fǒuzé hòuguǒ bùkān shèxiăng [Mandarin] otherwise outcome not-endure imagination 
(35)

这场火，幸亏消防队来得早。否则后果不堪设想。

"This fire, lucky was it that firemen arrived in good time [to put it out]. Otherwise, it would have caused unimaginable damages."

$\begin{array}{llllll}\text { Mehau } & \text { ganggang } & \text { cen } & \text { ditik } & \text { qi } & \text { nao ! }{ }^{14} \\ \text { much-preferred } & \text { just-now } & \text { take } & \text { underground } & \text { go } & \text { EM-SFP }\end{array}$

蛮好刚刚乘地铁启孬！ [Shanghai Wu dialect]

(EM-SFP $=$ emotive sentence-final particle )

"It would have been much better that we took the underground at the time." Mandarin equivalent : 刚才要是坐地铁去就好了。

Mengji-le zaudi mafang be

forget-ASP earlier buy-house SFP

猛记了早地马房把。 [Zhejiang Longyou 龙游 Wu dialect] ${ }^{15}$

"Should have bought a property earlier."

Mandarin equivalent : 早点买了房就好了

zăo xiăodé nǐ lái shíjià, wǒ hái yòng áojīngfèilì lei ? ${ }^{16}$

early know you come CM I still need make-great-effort SFM

[CM = counterfactual marker $]$

早晓得你来时价, 我还用謷精费力嘞? [Shaanxi 陕西 Shenmu 神木 dialect]

"If I were to know you would come, I wouldn't exhaust myself on the work."

zhèjiān fáng zài dà diăn-ér shíjià

this-CL room still big a-bit CM

这间房再大点儿时价。 [Shaanxi 陕西 Shenmu 神木 dialect.]

"If only the room were larger."

(33) is a conditional in disguise. The "if"-word is omitted, and the fixed expression 早知 道 zăo zhīdào 'know earlier' takes on a veridical proposition and yields a counterfactual hypothesis. In (34), 幸亏 xìngkūi 'It is lucky that ...' also takes on a veridical proposition, but it does not yield a counterfactual statement per se. Instead, it can often be followed by another routine statement: 不然的话 búrán de huà/ 否则 fǒuzé 'otherwise', which is a shorthand protasis and is a negation of the aforementioned veridical statement, pointing to the counterfactual opposite. On the other hand, (35) - (38) each contains a lexicalized device which takes in an antiveridical proposition and yields a counterfactual statement. These structures are few in number, but each is very familiar and frequently used in its own Chinese variant. And there may be many other dialects of Chinese which contain such fixed patterns of counterfactuality that remain to be identified and included in

\footnotetext{
${ }^{14}$ More in Jiang \& Wang (2016). As tone sandhi in Shanghainese is very complicated, it is customary for non-phonetic studies to omit tones in example sentences. Example (35) is from daily conversations taken down by the author as a native speaker of the Shanghai $\mathrm{Wu}$ language.

${ }^{15}$ Example collected in author's fieldwork taking recorded sound files. For (36)-(37), Romanization only reflects approximate pronunciation. Characters are also given in an attempt to mimic dialectal pronunciation.

${ }^{16}$ Example (37)-(38) taken from Xing (2002: 636-7). Romanization is based on the pronunciation in Mandarin and does not reflect the pronunciation in Shenmu dialect. According to Xing, 时价 'shijia' should be pronounced as $\mathrm{si}^{53} \mathrm{t}_{6 \mathrm{i}} \varepsilon^{21}$ and is a dedicated subjunctive marker.
} 
this inventory. These patterns invariably treat contingent worldly matters, hence the requirements on veridicality or antiveridicality can be readily met and verified. As a theoretical extension, in Jiang (2016), I adopt the criteria used by Rescher, who divides HISTORICAL COUNTERFACTUALS ${ }^{17}$ into TRUTHIFYING and FALSIFYING ones (Rescher 2007). By definition, truthifying counterfactuals denote cases when something-or-other-which did not actually happen-had happened. Then certain specifiable consequences would have ensued. On the other hand, falsifying counterfactuals denote cases when something-or-other-which actually did happen - had not happened. Then again, certain specifiable consequences would have ensued. In this light, Chinese explicit counterfactuals are of the same nature as historical counterfactuals, being classifiable into truthifying and falsifying ones. More importantly, the counterfactual markers are encoded means to truthify or falsify related propositions, yielding counterfactual statements. Given that explicit counterfactuals in Chinese are all real-life contingent, it can also be hypothesized that the implicit counterfactuals are real-life dependent as well, and are also classifiable into truthifying and falsifying ones. The weak features previously identified do not contribute directly to counterfactual meaning. Instead, they provide cues to help falsify or truthify the protasis proposition depending on the contribution made by the lexical items. 没有 méiyǒu 'negation-perfective' and 真的 zhēnde 'really' can now be viewed as typical falsifier and truthifier respectively. Even a totally unmarked conditional can also have falsifying or truthifying counterfactual readings, when the language user checks the veridicality and contingency of the protasis content against the topics right "in front of his eyes".

Does it make much sense to talk about FALSIFYING and TRUTHIFYING COUNTERFACTUALS in English in general, not just as HISTORICAL COUNTERFACTUALS? For languages with morphologically marked counterfactuals, it is probably less significant, and it also depends on whether a language has frozen falsifying and truthifying constructions. On the other hand, Chinese lacks explicit counterfactual morphology but makes abundant use of frozen falsifying frames and truthifying constructions, which can all be re-analyzed as hidden conditionals.

It is important to reiterate that both truthifying and falsifying apply to the domain of counterfactual statements or hypotheses and should not be confused with the meaning and use of indicative conditionals.

\section{Counterpossibles and a related puzzle}

This discussion is not complete without talking about the counterpossible conditionals, which get counterfactual readings because they have counter-possible protases, cf. Krakauer (2012). They are neither falsifying nor truthifying, since they do not point to a past or immediate contingency. They are counterfactual purely by content: ${ }^{18}$

\footnotetext{
${ }^{17}$ HISTORICAL COUNTERFACTUALS are a kind of counterfactual conditionals used to hypothesize alternatives in past history, either as an entertainment or as a serious effort in historiographical studies. Such counterfactuals are similar to the counterfactuals about ordinary life occasions in that they both hypothesize on alternatives to irrevocable past events. Cf. Ferguson (1997) and Evans (2014) for details, in addition to an introduction in Wikipedia under "Counterfactual History".

18 (39) is also called a COUNTER-IDENTICAL by Nickerson (2015).
} 


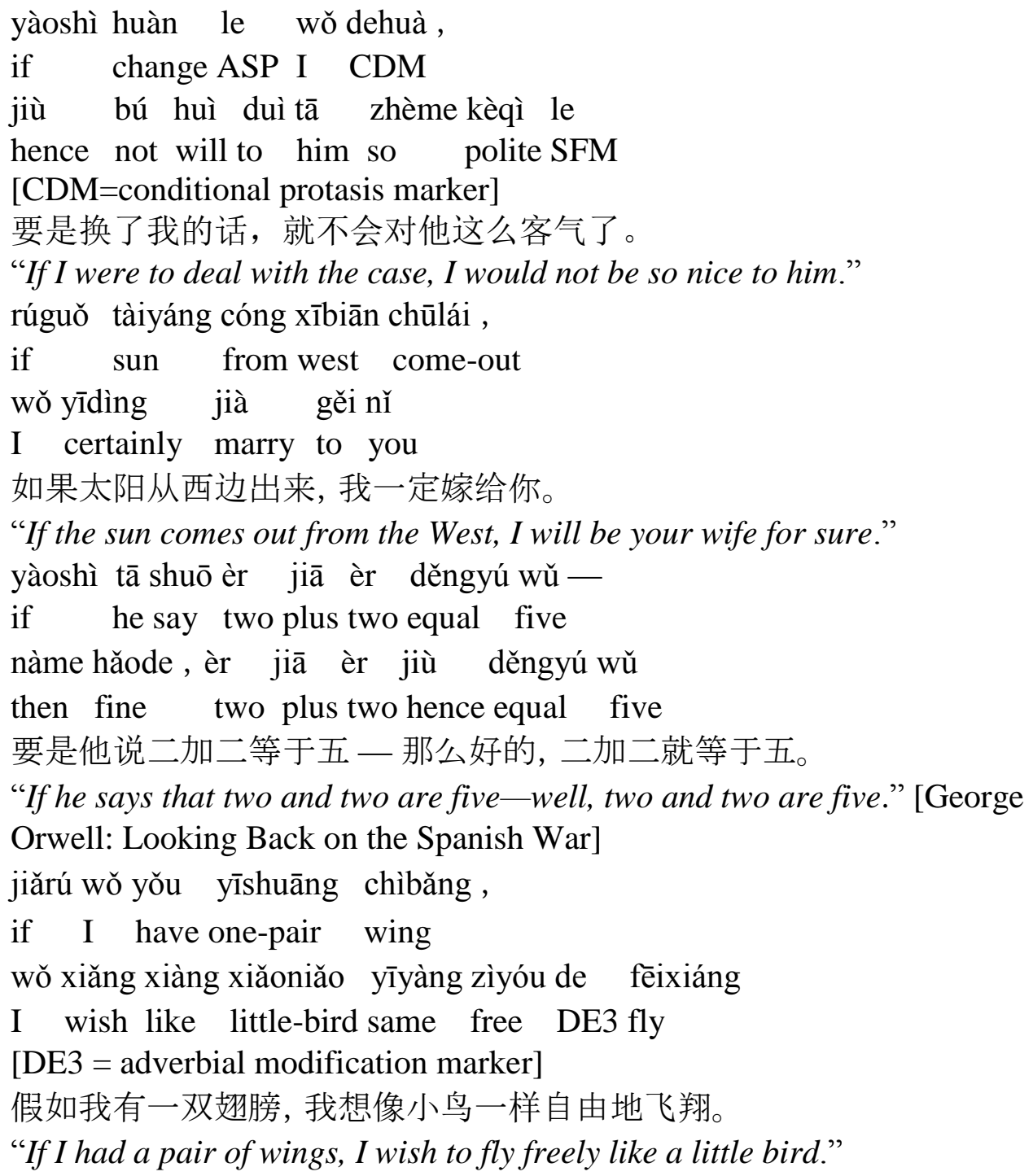

It is worth noting that the above sentences do not contain the explicit or implicit truthyfying or falsifying features. It is customary not to add such features, even though it is not impossible to add a feature or two of this kind. For example, adding 真的 zhēnde 'really' to (40) and (42) will also do, but not for (39) and (41). On the other hand, adding 早 zăo 'early' to any of the above examples is not acceptable. Nor is it at all possible to add 要不是 yàobúshì 'if-not-be' or 早知道 zăo zhīdào 'know earlier'. Note also that equivalents in English, as shown by (11) - (12), also show like features. They are counterfactuals without special morphological markers.

But that is still not the whole story, as there is another type of English counterfactuals that assume the form of indicatives. In live football commentary, one can often catch comments like "if the ball goes in, we go into extra time" or "if the ball goes in, we're looking at (another half an hour of) extra time", when the ball has in fact just been missed. ${ }^{19}$ Obviously, this is not a

\footnotetext{
${ }^{19}$ I thank Bjarke Frellesvig for pointing this case out to me and I thank an anonymous reviewer for supplying the two authentic examples given here.
} 
counterpossible but it also takes on the form of indicative or bare counterfactual. The football commentary case presented here bears much resemblance to the Chinese equivalent given as (25), which is also bare but is ambiguous between the indicative and the counterfactual readings. There is perhaps a cognitive reason for such uses, for both the languages. Counterfactual reasoning is after all a complicated thinking process requiring investment in cognitive effort. For an event that has just happened, one has two choices. Either he stands back and contemplates the event (taking a sip of coffee), then makes the comment - in the form of a subjunctive conditional. Or more commonly, he lets out his comment without much thinking - in the form of an indicative counterfactual, simply because he has no time to adjust, or he is watching the playback.

\section{Epilogue}

Studies of counterfactual conditionals have accumulated a vast literature, boasting some of the most stimulating achievements in philosophy and linguistics. But the study of Chinese counterfactuals remains to be a road less trodden, calling for more studies in all directions, so that more findings can be achieved and more consensus, reached. This paper proposes a unified descriptive framework of Chinese counterfactuals, which is tilted toward logico-semantic and inferential-pragmatic approaches. Two other recent works have provided general theoretical characterizations of Chinese counterfactuals. One is Yuan (2015), which provides broadly cognitive and cultural generalizations. The other is Jing-Schmidt (2017), which provides a broadly functional and pragmatic analysis in construction grammar.

This paper can be viewed as an exercise in SEMANTIC BOTANY, which is taken to precede any attempts at formalization and theorization, as it is necessary to establish first some minimal common ground on this much neglected and rather controversial topic in Chinese linguistics.

\section{Acknowledgements:}

I thank the three anonymous reviewers for many helpful comments. I also benefit a lot from the following sources: (1) discussions with my doctoral students Ka-Fat Chow, Chuansheng He, Eddy Maggie Yuying Wang, and Chun-wing Wong in the years 2006-12, when they worked on topics related to conditional-strengthening, counterfactuals, scalar model and donkey anaphora, (2) a series of meetings at a project-planning group at the Department of Philosophy, Chinese University of Hong Kong involving Leo Kam-ching Cheung, Leung-fu Cheung, Thomas Hun-tak Lee, Kaiyee Wong and myself in the years 2014-15, (3) comments from Bjarke Frellesvig, Nathan Hill, Jianhua Hu, Kiaer Jieun, Thomas Hun-tak Lee, Jo-wang Lin, Lutz Marten, Irina Nikolaeva, Haihua Pan and Yulin Yuan, who either read a draft version or listened to my earlier presentations at my SOAS job talk (March 2015), Third Symposium on Prominence and Locality in Natural Language, Beijing Language University (March 2015), Linguistic Seminar, Faculty of Oriental Studies, University of Oxford (February, 2017), and Symposium on Chinese in the Maritime Silkroad, the Chinese University of Hong Kong (April 2017). 


\section{References:}

Au, Terry K.-F. 1984. Counterfactuals: In reply to Alfred Bloom. Cognition 17(3): 289-302.

Au, Terry K.-F. 1983. Chinese and English counterfactuals: The Sapir-Whorf hypothesis revisited. Cognition 15(1-3): 155-187.

Bennett, Jonathan. 2003. A philosophical guide to conditionals. New York: Oxford University Press.

Bloom, Alfred H. 1981. The linguistic shaping of thought: A study in the impact of language on thinking in China and the West. Hillsdale, NJ: Lawrence Erlbaum Associates.

Bloom, Alfred H. 1984. Caution-The words you use may affect what you say: A response to Terry Kit-fong Au's "Chinese and English counterfactuals: The Sapir-Whorf hypothesis revisited", Cognition 17(3): 275-287.

Chao, Yuen Ren. 2011. A Grammar of Spoken Chinese. Berkeley: University of California Press.

Chao, Yuen Ren. 1968. A Grammar of Spoken Chinese. Beijing: The Commercial Press.

Chen, Guohua 陈国华. 1988 A Comparison between English and Chinese Hypothetical Conditionals 英汉假设条件句比较. Foreign Language Teaching and Research 《外语教 学与研究》,73: 10-19.

Cheng, Wenjie. 1985. Pictures of ghosts: A critique of Alfred Bloom's The linguistic shaping of thought. American Anthropologist87(4): 917-922.

Evans, Richard J. 2014. Altered pasts: Counterfactuals in history. London: Little, Brown.

Feng, Gary, and Yi, Li. 2006. What if Chinese had linguistic markers for counterfactual conditionals? Language and thought revisited. Conference paper of the 28th Annual Conference of the Cognitive Science Society, 1281-1286.

Ferguson, Niall (ed.). 1997. Virtual history: Alternatives and counterfactuals. London: Picador.

Harbsmeier, Christoph.1998. Science and civilisation in China,vol. 7, The Social Background; Part 1, Language and Logic in Traditional China. Cambridge: Cambridge University Press.

Hsu, Ching-fen. 2013. Counterfactual reasoning embodied in cognition rather than linguistic forms: Evidence from a Developmental Study in Chinese. Journal of Chinese Linguistics 41(2): 292-316.

Hsu, Ching-fen. 2014. Semantic-based mental representation of Chinese counterfactuals: evidence from a psycholinguistic study of Yaobushi. Language and Linguistics 15(3): 391-410

Jiang, Yan 蒋严. 2000. On the counterfactual reading of Chinese conditionals 汉语条件句的违 实解释. In Studies and Investigations on Chinese Grammar 10 《语法研究和探索: 十》, ed. Bojiang Zhang, 257-279, Beijing: The Commercial Press.

Jiang, Yan. 2014. On the lexical meaning of conditional connectives in Chinese. In Chinese Lexical Semantics: 15th Workshop CLSW 2014, Macao, China, June 9-12, 2014, Revised Selected Papers, ed. Xinchun Su and Tingting He, 43-54. Cham: Springer International Publishing AG.

Jiang, Yan. 2016. Chinese Pragmatics. In The Routledge Encyclopaedia of the Chinese Language, ed. Sin Wai Chan,. 184-202 Chapter 11,. Abingdon and New York: Routledge.

Jiang, Yan, and Yuying Wang. 2016. Counterfactual subjunctive assertions in Shanghai dialect, In Commemorative essays for Professor Yuen Ren Chao: Father of Modern Chinese 
Linguistics, ed. Andy C.-O. Chin, Kwok Bit-chee, and Benjamin K. Tsou, 193-201. Taipei: The Crane Publishing.

Jing-Schmidt, Zhuo. 2017. What are they good for? A constructionist account of counterfactuals in ordinary Chinese. Journal of Pragmatics 113: 30-52.

Krakauer, Barak L. 2012. Counterpossibles. Doctoral dissertation. Amherst, MA: University of Massachusetts.

Liu, Lisa G. 1985. Reasoning counterfactually in Chinese: Are there any obstacles? Cognition 21:239-270.

Lü, Shuxiang 吕叔湘. 1956. Aspects of the Chinese Grammar 《中国文法要略》. Beijing: The Commercial Press.

Nickerson, Raymond. 2015. Conditional Reasoning: The Unruly Syntactics, Semantics, Thematics, and Pragmatics of "If". New York: Oxford University Press.

Rescher, Nicholas. 2007. Conditionals. Cambridge, MA: The MIT Press.

Sanford, David H. 2003. If P, then Q: Conditionals and the foundations of reasoning ( $\left.2^{\text {nd }} \mathrm{ed}.\right)$. London and New York: Routledge.

Wang, Yuying 王宇贞. 2013. The Ingredients of Counterfactuality in Mandarin Chinese 《汉语 违实成分研究》. Beijing: China Social Science Press.

Wu, Cynthia H.-F. 1994. "If Triangles Were Circles ... " - a Study of Counterfactuals in Chinese and English. Taipei: The Crane Publishing.

Xing, Xiangdong 邢向东. 2002. A Study of Shenmu Dialect 《神木方言研究》. Beijing: Zhonghua Publishing.

Yeh, David, and Dedre Gentner. 2005. Reasoning counterfactually in Chinese: Picking up the pieces. In Proceedings of the Twenty-seventh Annual Meeting of the Cognitive Science Society, ed. Bruno G. Bara, Lawrence Barsalou, and Monica Bucciarelli, 2410-2415. Mahwah, NJ: Lawrence Erlbaum Associates.

Yong, Qian. 2016. A corpus-based study of counterfactuals in Mandarin. Language and Linguistics 17(6): 891-915.

Yuan, Yulin 袁毓林. 2015. Counterfactual Expressions in Chinese and the Distinctive Thinking They Reflect 汉语反事实表达及其思维特点. Social Sciences in China 《中国社会科学》 8: 126-144.

\author{
Yan JIANG \\ Department of Linguistics \\ SOAS, University of London \\ https://www.soas.ac.uk/staff/staff104913.php | \\ https://sites.google.com/site/vanjianglinguisticssoaslondon/ \\ yig@soas.ac.uk
}

